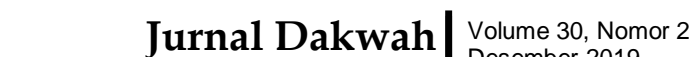 \\ RISALAH| \\ DOI: $10.24014 /$ jdr.v30i2.8510
}

\section{TERAPI PENYEMBUHAN AUTIS MELALUI PENDEKATAN KONVENSIONAL DAN ZIKIR DI PEKANBARU DAN YOGYAKARTA}

\author{
Miftahuddin ${ }^{1}$, M. Fahli Zatrahadi ${ }^{2}$, Suhaimi $^{3}$, Darmawati ${ }^{4}$, Dea Aulia ${ }^{5}$ \\ $1,2,3,4,5$ Universitas Islam Negeri Sultan Syarif Kasim Riau \\ Email: miftahuddin@uin-suska.ac.id
}

\author{
Kata kunci \\ Terapi Alternatif \\ Autis, Terapi \\ Konvensional \\ Autis, Terapi Zikir
}

Keywords

Autistic alternative

therapy, Autistic

conventional

therapy, Dhikr

Therapy

\begin{abstract}
Abstrak
Seiring berkembangnya ilmu pengetahuan terdapat banyak jalan anternatif untuk menyembuhkan autis, dengan melalukan berbagai macam terapi seperti yang digunakan oleh Sekolah Permata Hati Pekanbaru dan Sekolah Khusus Taruna Al-Qur'an Yogyakarta. Tujuan penelitian ini untuk mengetahui terapi penyembuhan autis melalui pendekatan konvensional dan pendekatan zikir. Penelitian ini menggunakan pendekatan kualitatif dengan membandingkan terapi konvensional dan zikir. Subjek dalam penelitian ini terdiri klien, terapis dan keluarga klien. Hasil penelitian menunjukkan bahwa terapi melalui pendekatan konvensional di Sekolah Permata Hati menggunakan 5 terapi 1.Terapi bicara, 2. Terapi okupasi, 3. Terapi interaksi sosial, 4. Terapi sensori interaksi, dan 5. Terapi makan, sedangkan terapi zikir di Sekolah Khusus Taruna Al-Qur'an Yogyakarta menggunakan terapi zikir dengan melihat hasil zikir pagi petang dengan beberapa tahapan 1. Asesment, 2. Menentukan tujuan, 3. Pola pembiasaan perilaku, 4. Perubahan tingkah laku. Penelitian ini menunjukkan bahwa rumah terapi konvensional menitikberatkan kesehatan secara fisik, sedangkan terapi zikir menitikberatkan pada faktor rohani.
\end{abstract}

\footnotetext{
Abstract

On account of the development of science, there are recently many alternative treatments to cure autism through various kinds of therapies such as used by the Permata Hati Pekanbaru School and the Islamic Boarding School of Taruna Al-Quran in Yogyakarta. The purpose of the current paper was to determine healing therapy on autism through conventional and Dhikr approaches. Conducted through qualitative approach, the chosen subjects consisted of clients, therapists and client families. The results of this study showed that therapy through conventional approaches at the Permata Hati Pekanbaru School used 5 treatments; 1. Speech therapy, 2. occupational therapy, 3. social interaction therapy, 4. sensory interaction therapy, and 5. eating therapy. Otherwise, the Dhikr therapy in the Islamic Boarding School of Taruna Al-Quran in Yogyakarta noticed the results of the morning evening Dhikr through several stages; 1. assessment, 2. determining goals, 3. patterns of habitualizing behavior, 4. and changes in behavior. The project showed that the Permata Hati Pekanbaru therapy focused on physical health, while the Dhikr therapy focused on spiritual factors.
} 
Miftahuddin, M.Fahli Zatrahadi, Suhaimi,

Darmawati, Dea Aulia

Terapi Penyembuhan Autis Melalui Pendekatan.....
Jurnal Dakwah Risalah

Vol. 30 No. 2. Desember 2019: Hal 227-239

\section{Pendahuluan}

Rendahnya peran serta kesadaran orang tua dan terapis dalam menerapkan terapi yang digunakan kepada seorang anak dengan gangguan autis membawa dampak pada pencapaian kesembuhannya. Peran orang tua dalam membantu proses penyembuhan anaknya harus dapat memilih tempat terapi yang benar, sehingga seorang terapis yang memiliki kompetensi akan memberikan saran terapi ringan untuk dilakukan oleh orang tua di rumah. Apabila peran antara orang tua dan terapis sudah diterapkan maka proses penyembuhan akan semakin cepat (Agustina, 2017). Ketenangan jiwa merupakan hal yang penting dan menjadi salah satu prioritas utama setiap individu adalah kehidupan yang nyaman (Ifdil et al, 2019), sayangnya banyak orang tua yang merasa rendah diri dan menggap punya anak dengan gangguan autis sulit disembuhkan dan hal ini justru menjadikan orang tua merasakan ketidak tenangan jiwa (Kusumastuti, 2018).

Kata autis biasanya digunakan dalam bidang psikiatri untuk menunjukkan gejala menarik diri (Mangunsong, 2009). Autisme adalah seseorang yang memiliki kelainan pada perkembangan sistem saraf yang kebanyakan diakibatkan oleh faktor hereditas dan dapat dideteksi sejak bayi berusia 6 bulan (Wirapati, 2018), apabila anak dapat dideteksi dan diterapi sedini mungkin akan membuat anak tersebut dapat menyesuaikan diri dengan anak normal lainnya, karena salah satu karakteristik anak yang mengidap kelainan ini ialah kesulitan dalam membina hubungan sosial, berkomunikasi secara normal maupun memahami emosi serta perasaan orang lain (Klin, Jones, Schultz, Volkmar, \& Cohen, 2002).

Autisme adalah gangguan perkembangan yang komplek dan memengaruhi perilaku, sehingga mengakibatkan kurangnya kemampuan komunikasi (Nurhidayati, 2015), hubungan sosial dan emosional dengan orang lain, serta sulit untuk memiliki keterampilan dan pengetahuan yang diperlukan sebagai anggota masyarakat (Risdayati \& Merianto, 2016).

Adapun berbagai gambaran gejala autis yang terdapat pada masa kanak-kanak yaitu: menikmati bermain seorang diri (kesendirian) yang begitu hebat, keterlambatan dalam perkembangan bahasa, menghafalkan sesuatu tanpa berfikir, stereotip, kontak mata dan hubungan dengan orang lain yang buruk, melakukan aktivitas spontan tanpa batas, obsesi terhadap cemas dan takut akan perubahan, lebih menyukai benda-benda mati ataupun gambar (Yunus, 2016).

Gejala autisme dapat dikelompokkan kedalam dua kategori utama, kategori pertama ialah gangguan interaksi sosial dan komunikasi gejalanya dapat dilihat dari masalah kepekaan terhadap lingkungan sosial dan gangguan penggunaan bahasa verbal maupun nonverbal, sementara kategori kedua meliputi pola pikir, minat dan perilaku yang terbatas serta bersifat pengulangan contohnya gerakan repetitif seperti mengetukngetuk atau meremas tangan serta merasa kesal apabila rutinitas yang dilakukannya terganggu. Selain itu, penyandang autis juga cenderung memiliki masalah belajar dan kondisi kejiwaan lainnya seperti gangguan hiperaktif atau Attention Deficit Hyperactivity Disorder (ADHD), gangguan kecemasan atau depresi (Desiningrum, 2017).

Autisme termasuk kedalam salah satu gangguan perkembangan yang merupakan bagian dari gangguan spektrum autisme atau Autism Spectrum Disoders (ASD) dan juga merupakan salah satu dari lima jenis gangguan dibawah payung Gangguan Perkembangan Pervasif atau Pervasive Development Disorder (PDD). Autisme bukanlah sebuah penyakit kejiwaan melainkan gangguan yang terjadi pada otak 
sehingga otak tersebut tidak dapat berfungsi selayaknya otak normal dan hal ini termanifestasikan pada perilaku penyandang autisme (Wikipedia, n.d.).

Setiap orang tua tentunya mengiginkan anak yang sehat jasmani dan rohani serta tercapai semua perkembangan dalam semua tahap umur perkembangan yang dilalui, namun tidak semua orang tua mendapatkan keberuntungan (Rifai, 2016). Anak dengan gangguan autisme tumbuh berbeda dengan anak sebayanya dan tidak jarang mereka menerima perlakuan tidak menyenangkan dari masyarakat sekitar. Semua itu diperparah lagi oleh pandangan lama yang menyatakan autis adalah sesuatu yang tidak dapat disembuhkan, sehingga mereka tidak memiliki harapan untuk dapat hidup sebagai individu yang paripurna dan mandiri sebagaimana anak lainnya (Hadi \& Zubaidah, 2015).

Orang tua yang memiliki seorang anak yang mengidap gangguan ini merasa malu dan merasa itu sebagi aib, orang tua tersebut banyak menganggap anak autis tidak memiliki masa depan, itu semua juga didukung oleh sistem pendidikan formal yang ada di negara ini tidak dapat menangung sekolah reguler yang siap menerima dan menangani anak dengan gangguan autis, itu adalah ketakutan yang teramat berat yang dirasakan orang tua dengan anak yang memiliki gangguan autis (Sari \& Yudhatama, 2017).

Namun dengan berkembangnya ilmu pengetahuan kini telah ada berbagai macam terapi yang dilakukan untuk menyembuhkan anak penderita autis. Ada 10 macam terapi yang sering dilakukan yaitu: 1) Applied Behavioral Analysis (ABA), 2) Terapi Wicara, 3) Terapi Okupas, 4) Terapi Fisik, 5) Terapi Sosial, 6) Terapi Bermain, 7) Terapi Perilaku, 8) Terapi Perkembangan, 9) Terapi Visual, 10) Terapi Biomedik. Terapi tersebut didapatkan setelah melakukan riset dan menemukan bahwa gejala autis ternyata diperparah oleh gangguan metabolisme yang akan berdampak pada gangguan fungsi otak (Hasnita \& Hidayati, 2017).

Oleh karena itu, anak autis harus diperiksa secara intensif, meliputi pemerikasaan darah, urin, fases, dan rambut. Semua hal yang berhubungan dengan abnormal dibereskan, sehingga otak menjadi bersih dari gangguan. Ternyata lebih banyak anak mengalami kemajuan bila mendapat terapi komprehensif yaitu terapi dari luar dan dari dalam tubuh sendiri (biomedis). Sekarang ini bermunculan tempat terapi dan sekolah khusus untuk membantu perkembangan autisme, banyak jenis terapi yang digunakan dengan teknik konvensional atau yang biasa dilakukan, seperti terapi gelombang otak, terapi wicara, terapi fisik, terapi musik yang telah ditulis di atas dan masih banyak lagi yang biasa digunakan di sekolah khusus anak autisme. Terapi konvensional ini bertujuan untuk membentuk perilaku positif dan mengembangkan kemampuan lain yang terhambat (Purwanto, 1998). Salah satu sekolah yang menerapkan ini di Kota Pekanbaru ialah Permata Hati.

Terapi zikir adalah salah satu pengobatan alternatif islami dengan menggunakan kekuatan doa dan zikir sebagai pondasinya. Zikir adalah cara untuk menginggat Allah sesuai dengan al-qur'an surat an-nisa (4): 103 (Yayasan Penyelenggara Penterjemah atau Penafsir Al-Qur'an, 2004) yang artinya:

"Maka apabila kamu telah menyelesaikan shalat(mu), ingatlah Allah di waktu berdiri, di waktu duduk dan di waktu berbaring. Kemudian apabila kamu telah merasa aman, maka dirikanlah shalat itu (sebagaimana biasa). Sesungguhnya shalat itu adalah fardhu (kewajiban) yang ditentukan waktunya atas orang-orang yang beriman". 
Zikir ialah ucapan yang dilakukan dengan lidah untuk mengingat akan Tuhan dengan hati, ucapan dan ingatan yang menyucikan dan membersihkan dari sifat-sifat yang tidak layak untuk-Nya (Astuti, Suryono, Widyawati, Suwondo, \& Mardiyono, 2017). Kekuatan zikir terdapat pada surat Al-Baqarah: 125 yang artinya "Maka berzikirlah (ingatlah) kepada-Ku, niscaya Aku akan mengingati kamu sekalian".

Salah satu sekolah yang menggunakan terapi zikir dan sangat fenomenal berada di Yogyakarta, yakni Sekolah Khusus Taruna Al-qur'an. Apabila terapi konvensional dan terapi zikir dan ditambah dengan memakan-makanan yang halal dapat menyembuhkan gangguan autisme dan anak tersebut dapat hidup secara mandiri (Hapsari, 2016).

Oleh karena tujuan penelitian ini untuk mengetahui terapi penyembuhan autis melalui pendekatan konvensional yang dijalankan oleh Sekolah Permata Hati Pekanbaru dan pendekatan zikir di Sekolah Khusus Taruna Al-Qur'an Yogyakarta.

\section{Metode}

Penelitian ini berjenis kualitatif. Penelitian ini menghasilkan data deskriptif dengan membandingkan dua jenis pendekatan dalam terapi sehingga mendapatkan informasi tentang penggunaan terapi dalam penyembuhan gangguan Autis. Lokasi penelitian ini di Sekolah Permata Hati Pekanbaru dan Sekolah Khusus Taruna AlQur'an Yogyakarta. Subjek penelitian ini yakni klien yang terdiri dari 2 orang dari setiap sekolah, terapis berjumlah 2 orang dari setiap sekolah dan keluarga yang berjumlah 2 orang dari setiap sekolah.

\section{Hasil dan Pembahasan}

Terapi zikir pada anak autis di Sekolah Khusus Taruna Al-Qur'an Yogyakarta terdiri dari beberapa tahapan: pertama melakukan asesmen, asesmen menjadi langkah awal dalam mengidentifikasi perilaku anak, asesmen dilakukan dengan beberapa tahap, di mana tahapan ini dilakukan wawancara dengan orang tua sebagi bentuk penggalian informasi secara detail tentang anak. Biasanya di sekolah ini sebagian orang tua sudah terlebih dahulu mempunyai data hasil tes psikologi yang mana tes tersebut untuk mengetahui kemampuan kecerdasan seseorang dan faktor inteligensi atau faktor kepribadiannya, tetapi apabila anak tidak memiliki hasil tes itu maka sekolah akan memberikan surat rujukan untuk tes di rumah sakit yang telah bekerjasama dengan pihak sekolah dan biasanya juga langsung di asesmen oleh kepala sekolah sendiri karena kepala sekolah juga merupakan seorang psikolog.

Kedua, menentukan tujuan (goal setting), setelah dilakukan asesmen maka selanjutnya akan dibuatkan program Rencana Program Treatment Santri (RPTS), selanjutnya penilaian dari terapis akan dibuatkan Laporan Program Treatment Anak (LPTA), sehingga dari hasil RPTA dan LPTA nantinya akan bisa dibuatkan seuah program yang akan diberikan kepada anak autis.

Ketiga, pola pembiasan perilaku, pada tahap ini terapis merancang strategi untuk membuat anak mencapai perubahan perilaku yang diinginkan dengan cara: mengajarkan anak makan dan minum yang baik dalam perspektif islam, anak autis memiliki daftar menu makanan dan minuman yang diperbolehkan untuk dikomsumsi dan juga termasuk daftar yang tidak diperbolehkan untuk dikomsumsi, untuk anak autis harus dihindari dari makanan yang mengandung tepung, susu, zat pemanis buatan dan pewarna. 
Selanjutnya mengajarkan salat berjamaah yang merupakan kegiatan wajib dan ini biasanya dilakukan pada saat salat duha. Selanjutnya mengajarkan berwudu dengan baik sesuai dengan syariat islam, mengajarkan akhlak dengan menjelaskan definisi akhlak yang baik, bentuk-bentuk akhlak yang baik, serta keutamaan-keutamaan yang akan diperoleh hamba jika mampu mengamalkan akhlakul karimah dalam kehidupan sehari-hari. Melalui materi-materi ini anak akan diajari sifat-sifat kejujuran, moralitas dan adab-adab dalam hidup seperti sifat dan akhlak yang diajarkan oleh Rasulullah SAW. Terakhir, mengajarkan hafalan zikir, hafalan Alquran merupakan program yang diwajibkan kepada seluruh anak yang mana dimulai dari ayat-ayat pendek dan alma'surah, sedangkan zikir diberikan dalam bentuk perintah kepada setiap anak untuk melaksanakan ibadah zikir dalam setiap selesai salat duha berjamaah.

Keempat, teknik perubahan tingkah laku. Teknik ini lebih mengarah kepada perubahan perilaku serta cara berfikir anak. Adapun teknik yang dipakai dengan menghilangkan atau mengurangi perilaku yang tidak dikehendaki dengan cara; penghapusan atau extinction (terapis mengacuhkan perilaku negatif anak dan tetap melanjutkan intruksi yang diberikan hal ini dilakukan secara berulang-ulang agar anak dapat memahami bahwa perilaku yang ia tunjukkan ialah perilaku yang tidak baik).

Satisasi atau satitation (ini merupakan teknik penjenuhan, seperti subjek B yang memuncullkan perilaku berteriak-teriak, penerapannya subjek B diberikan waktu lebih untuk berteriak di luar ruangan dan waktunya diberikan pada sebelum memulai kegiatan, pertengahan kegiatan dan akhir kegiatan) pemberian hukuman diberikan berdasarkan catatan pelanggaran yang melebihi batas, dari pihak pengasuh memberikan batasan lima kali, hukuman tersebut berupa pengurungan di dalam sel sesuai dengan peraturan awal, di dalam sel tersebut anak akan mengerjakan tugas seperti hafalan surah pendek.

Selanjutnya teknik yang dipakai dalam teknik perubahan tingkah laku yaitu mengembangkan perilaku yang dikehendaki dengan cara: penguatan positif atau positive reinforcement (memberikan dukungan yang menyenangkan setelah perilaku yang diharapkan cendrung akan diulang, meningkat dan menetap di masa yang akan datang serta perilaku baik akan diberikan apresiasi berupa reward yang disukai anak. Kartu berharga atau token ekonomi (di dalam kartu berharga ini apabila anak sering menunjukkan perilaku yang tidak baik maka dia tidak akan diberikan fasilitas yang ia sukai, tetapi apabila ia menunjukkan perilaku baik maka dia akan diberikan reward yang sudah dijanjikan dan diberikan fasilitas yang ia sukai. Kartu berharga ini bertujuan untuk mengembangkan dan mempertahankan perilaku baik yang ditunjukkan anak), time out (ialah teknik penyisihan sementara dan berdurasi lebih sebentar dari teknik hukuman, apabila anak melakukan perilaku yang tidak baik seperti keributan, maka dia akan dipindahkan ke tempat lain seperti di luar ruangan dan akan diberikan tugas untuk beristigfar).

Pelaksanaan terapi zikir melalui beberapa tahap yaitu: pertama, melakukan asesment. Asesment adalah suatu proses pengumpulan informasi yang akan digunakan untuk membuat suatu pertimbanagan dan keputusan yang berhubungan dengan seorang anak. Tujuan utama dari Asesment yaitu untuk memperoleh data yang lengkap sehingga dapat digunakan sebagai bahan pertimbangan dalam merencanakan program pelatihan bagi anak autis.

Dengan adanya asesemen yang baik diawal maka dapat diketahui perilakuperilaku yang bermasalah pada anak sehingga terapi yang akan dilakukan akan 
memberikan hasil yang memuaskan. Sebaliknya, jika asesmen tidak dilaksanakan dengan baik hal ini akan menjadi hambatan dalam proses terapi dan keberhasilan terapi menjadi kurang efektif dan efisien.

Kedua, menentukan tujuan (goal setting), setelah mengetahui apa yang dibutuhkan melalui asesmen dan observasi pada anak autis, selanjutnya akan dibuatkan program yaitu rencana program treatment santri (RPTS). RPTS program treatment yang digunakan untuk mengasuh anak autis, karena setiap anak mempunyai kebiasaan yang dilakukan dengan cara yang berbeda. Selanjutnya, penilaian dari terapis akan dibuatkan laporan program treatment anak. Sehingga dari hasil RPTA dan LPTA nantinya bisa dibuatkan sebuah program yang akan diberikan kepada anak autis.

Contoh kasus bentuk-bentuk perilaku maladaptif yang muncul seperti terjadi pada AJ yaitu tidak dapat mengontrol emosinya ketika menginginkan sesuatu sehingga cepat sekali marah, adalagi NF ketika sedang kegiatan di kelas atau salat dia tidak bisa diam. Dari hasil pengamatan perilaku yang dimunculkan anak autis di lapangan menjadi sebuah data dan bahan untuk melanjutkan ketahap selanjutnya, yaitu dibuatkan Rencana program penyembuhan perilaku (RPPP). Dimana isi RPPP tersebut terdiri dari latarbelakang, yaitu kesimpulan asesmen yang telah dinilai, seperti perilaku yang tidak diinginkan, durasi perilaku, frekuensi perilaku yang dimiliki anak dan juga kesimpulan permasalah perilaku yang dimiliki selain itu terdapat solusi dan rencana terapi yang diberikan.

Ketiga pola pembiasaan perilaku, Setelah tahapan tujuan terapi ditentukan oleh kepala sekolah, dan terapi sesuai dengan hasil asesmen yang sudah diolah. Maka terapis merancang strategi untuk membuat anak mencapai perubahan perilaku yang dinginkan.

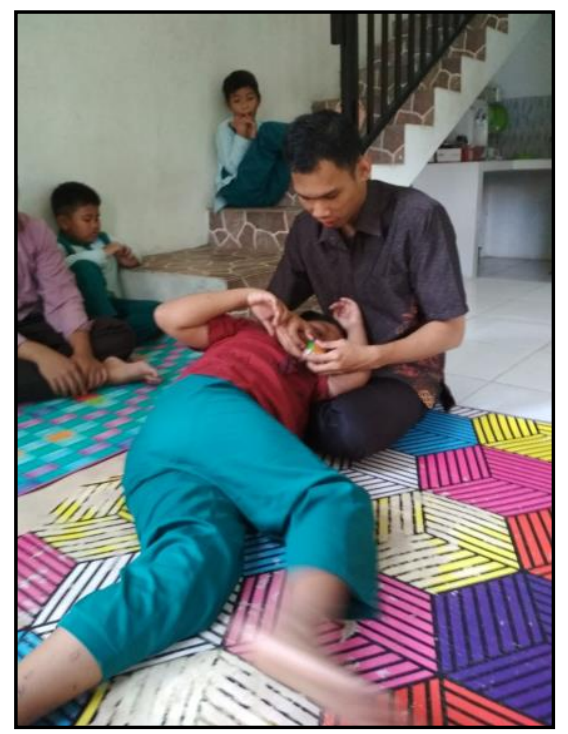

Sumber Hasil Penelitian

Gambar 1. Proses Terapi Zikir Yang Dilakukan Terapis

Jadi, hasil asesmen memang sangat diperlukan untuk membuat tujuan dan juga untuk merumuskan intervensi dalam menangani anak autis. Adapun strategi yang dirancang ialah:

a. Mengajarkan makan dan minum yang baik sesuai dengan perspektif islam 
Konsep makan dan minum yang baik dalam persfektif islam sebaimana di ajarkan oleh Rasulullah SAW mengacu kepada dua hal, pertama : makan dan minum yang baik dilihat dari jenis makanan dan minuman yang di konsumsi, kedua; makan dan minum yang baik dilihat dari etika yang melaksanakan (prose) makan dan minum.

Jenis makanan dan minuman yang baik dalam islam dikenal dengan istilah halal dan baik (halalan toyyibah), kata halal meliputi makanan dan minuman harus diperoleh dari usaha yang halal, dibeli dari tempat yang halal dan dari hasil uang yang halal, kemudian kata baik meliputi dua kriteria yaitu memiliki manfaat dan tidak mengandung mudharat. Kriteria "memiliki manfaat" ditujukkan dari makanan dan minuman yang berdampak baik bagi kesehatan tubuh seingga dengan mengkonsumsinya dapat meningkatkan kesehatan dan memaksimalkan stabilitas fungsi organ tubuh. Kemudian kriteria kedua adalah "tidak mengandung mudharat" ini ditunjukkan dengan tidak adanya reaksi negatif ketika (sedang atau setelah) mengkonsumsi makanan dan minuman tersebut.

\section{b. Mengajarkan Salat Berjamaah}

Kegiatan sholat berjamaah merupakan kegiatan wajib yang dilakukan oleh anak. Meskipun anak-anak autis memang belum sepenuhnya bisa mengikuti kegiatan sholat dengan tertib tetapi tujuan utama dalam pembiasaan perilaku adalah untuk menciptakan habit untuk anak.

c. Mengajarkan Berwudu Yang Baik Sesuai Dengan Syariat Islam

Bimbingan berwudu tidak hanya memberikan tatacara berwudu namun secara bersamaan memberikan pendidikan kepada anak untuk belajar fokus atau memperhatikan penuh aktivitas yang sedang dilakukan. Dengan mengarahkan anak untuk bersikap tenang ketika melaksanakan berwudu, secara tidak langsung mendidik anak untuk belajar menyadari hal-hal yang semestinya dilakukan oleh anak tidak dengan tergesa-gesa.

Apalagi jika pendidikan ini diaplikasikan kepada anak yang memiliki karakter yang hyperaktif, secara tidak langsung dapat menekan atau menurunkan tingkat hyperaktifnya. Sebab, anak hyperaktif yang diajarkan untuk diam dan tenang ketika berwudhu, kemudian dilakkukan secara berulang-ulang serta diaplikasikan dalam kegiatan lain dalam aktifitas sehari-hari, otomatis akan mengurangi kesempatan anak untuk berperilaku hyper dan dengan sendirinya kecenderungan tersebut akan menurun.

d. Mengajarkan Akhlak

Pendidikan akhlak diberikan kepada anak setiap hari, setelah selesai melaksanakan salat duha berjamaah, aspek-aspek yang dijelaskan dalam pendidikan akhlak tersebut menyangkut balasan yang akan Allah SWT berikan kepada orang yang tidak berperilaku baik terhadap sesama. Keutamaan akhlak dijelaskan sebagai motivasi supaya anak semangat dan berlomba-lomba dalam berakhlakul karimah dan hukuman atau ancaman juga dijelaskan supaya muncul rasa takut sehingga anak enggan untuk meninggalkan atau tidak berakhlak baik dalam kehidupan sehari-hari.

e. Mengajarkan Hafalan dan Zikir

Hafalan Alquran, merupakan program kegiatan yang diwajibkan kepada seluruh untuk menghafal Alquran dimulai dari ayat-ayat pendek dan al-ma'surah. Program 
hafalan Alquran memiliki orientasi ganda, pertama: untuk mencetak generasi qurani (berwawasan dan berakhlak qurani), dan kedua: untuk mengalihkan anak yang memiliki kebiasaan berbicara lebih dari anak pada umumnya, supaya kebiasaannya dalam berbicara yang tidak memiliki faedah diganti dengan bacaan-bacaan Alquran.

Pendidikan zikir diberikan dalam bentuk perintah kepada seluruh anak untuk melaksanakan ibadah zikir tersebut dalam setiap selesai salat Duha yang berjamah. Hal tersebut dimaksudkan supaya anak memiliki kebiasaan baru yang bernilai ibadah, namun juga mencegah anak dari berbicara banyak hal atau berkegiatan lain setelah melaksanakan salat. Begitu juga pembiasaan zikir dapat berfungsi melatih perkembangan bahasa verbal anak terutama pada anak yang memiliki hambatan pada speech delay.

Keempat, teknik perubahan tingkah laku, anak autis terkadang menunjukkan tingkah laku yang berlebihan terhadap situasi tertentu. Anak autis biasanya menunjukkan perilaku agresif dibanding dengan teman-temannya. Terapi Alquran bertujuan untuk mengubah perilaku dan membantu anak untuk bisa mengontrol perilaku serta bisa mengendalikan tindakan mereka. Diharapakan anak mampu mengendalikan reaksi berlebihan, kemarahan, serta menjadikan lebih tenang. Terapi perilaku lebih mengarah kepada perubahan perilaku serta cara berfikir anak.

Dalam teknik perubahan perilaku pada anak autis yang dikembangkan teori behavior ada dua yakni, menghilangkan atau mengurangi tingkah laku yang tidak di kehendaki dan mengembangkan tingkah laku yang dikehendaki. Dalam teori behavior banyak macam teknik yang ada tapi tidak semua teknik bisa digunakan secara langsung dalam penanganan anak autis. Teknik yang dipakai di Pondok Sekolah Khusus Taruna Al-Qur'an Yogyakarta adalah sebagai berikut:

a. Menghilangkan atau mengurangi perilaku tidak di kehendaki

1) Penghapusan (Extinction)

Dalam teknik penghapusan ini para pengasuh dan guru-guru memberikan suatu perlakuan kepada perilaku anak berupa mengacuhkan atau tidak memedulikan perilaku negatif yang dimunculkan oleh anak dan segera merespon jika menunjukkan perilaku positif. Perilaku anak juga harus diidentifkasi terlebih dahulu, sehingga tau yang mana yang diberi teknik penghapusan.

\section{2) Satisasi (Satitation)}

Teknik ini merupakan teknik penjenuhan, artinya di dalam teknik ini anak dibuat jenuh terhadap suatu tingkah laku, sehingga dia tidak lagi bersedia melakukannya.

3) Pemberian Hukuman

Sekolah Khusus Taruna Al-Qur'an Yogyakarta tidak memberikan hukuman fisik, dikhawatirkan hukuman fisik dpaat menimbulkan kebencian pada pribadi anak dan hukuman fisik ini juga tidak menimbulkan efek yang lama, tetapi efek sementara. Teknik pemberian hukuman dilakukan berdasarkan catatan pelanggaran anak yang melebihi batas. Pihak pengasuh memberikan batasan pelanggaran sebanyak lima kali, lebih dari lima kali anak akan menerima hukuman berupa pengurungan di sel sesuai dengan peraturan yang disampikan diawal. Anak akan dimasukkan ke dalam sel dengan mengerjakan tugas seperti hafalan surah pendek. Berapa lama hukuman ini tidak ditentukan, tetapi bisa dikukur dengan cara melihat anak bisa sadar akan perilakunya yang salah dan anak bisa dapat menerima nasehat dari pengasuh. 
b. Mengembangkan tingkah laku yang dikehendaki

1) Penguatan Positif (positif reinforcement)

Penguatan positif (positif reinforcement) adalah memberikan dukungan yang menyenangkan setelah tingkah laku yang diharapakan ditampilkan oleh anak yang bertujuan agar tingkah laku yang diharapkan cenderung akan diulang, meningkatkan dan menetap dimasa yang akan datang. Dalam hal ini adalah melihat perilaku baik yang dimunculkan oleh anak dan perilaku yang baik ini dipelihara. Tidak lupa juga perilaku baik juga diberikan apresiasi pada anak berupa reward yang disukai anak.

\section{2) Kartu Berharga (Token Ekonomi)}

Kartu berharga (token ekonomi) bertujuan untuk memngembangkan perilaku yang diharapakan pada anak dengan cara pemberian reinforcement dengan token. Token diartikan sebagai tanda atau isyarat yang dapat diberikan kepada anak, selanjutnya token tersebut dapat ditukarkan untuk mendapatkan hadiah yang disepakati diawal.

\section{3) Time Out}

Teknik ini serupa dengan teknik hukuman tetapi durasi waktunya lebih sebentar dibandingkan dengan teknik penyisihan sesaat (time out). Biasanya anak yang melakukan keributan di dalam kegiatan akan dipindahkan tempat yang awalnya gabung dengan teman-teman tetapi disisihkan di luar dengan durasi lima menit. Biasanya anak dibiarkan saja di luar kegiatan tapi juga terkadang anak diberi tugas untuk beristighfar.

Terapi konvensional di Rumah Terapi Permata Hati tidak pernah menerima siswa banyak karena mereka menganggap itu tidak efektif. Rumah terapi ini paling banyak menerima siswa 10 orang. Di Rumah Terapi Permata Hati jadwal masuk nya jam 8 sampai jam 14.30. Terapi yang digunakan di Rumah Permata Hati sendiri memiliki 5 terapi, yaitu: terapi bicara, terapi akupasi (bermain), terapi interaksi sosial, terapi sensori intekrasi dan terapi makan (motorik mulut).

Kelebihan dari Rumah Terapi Permata Hati ialah memakai terapi makan, terapi makan ini berfungsi menjaga pola makan anak dengan menerapkan apa saja makanan yang harus dimakan dan apa saja yang harus diberikan pada anak, karena apabila tidak sesuai maka anak akan eror dan pross pemulihannya butuh waktu 2-3 minggu. Apabila erornya lama maka perlu diberikan garam yang banyak ke makanan anak agar bisa cepat normal.

Rumah Terapi Permata Hati juga menerapkan 2 T yakni tegas dan tega dan ini yang selalu ditekankan kepada orang tua anak dan hal tersebut juga akan berpengaruh terhadap kelakuan anak. Melakukan kerjasama dengan dokter merupakan hal yang penting karena dapat memperkecil terjadinya gizi tidak seimbang pada anak autis dengan cara memberikan obat-obatan yang sesuai dengan kebutuhan anak.

Terapi melatih kontak mata dengan cara melatih kontak mata anak yaitu anak harus berhadapan dengan kita lalu dipanggil nama mereka, apabila mereka melihat maka meraka akan diberikan reward, tetapi apabila tidak ada respon dari sang anak maka lakukan itu secara berulang dan apabila tidak ada respon juga maka akan dibantu oleh pendamping dengan memberikan kata "lihat ibu". Selain itu dalam melatih kontak mata Rumah Permata Hati melakukan dengan cara menyuruh anak memindahkan bola dari keranjang atau menggunakan lampu ketika membaca. 
Terapi konvensional di Rumah Permata Hati ini memiliki 5 terapi yang diterapkan dalam penanganan anak autis yaitu:

1. Terapi Bicara

Semua anak dengan autisme mempunyai kesulitan dalam bicara dan berbahasa. Biasanya hal inilah yang paling menonjol. Banyak pula individu autistik yang nonverbal atau kemampuan bicaranya sangat kurang. Kadang-kadang bicaranya cukup berkembang, namun mereka tidak mampu untuk memakai bicaranya untuk berkomunikasi/ berinteraksi dengan orang lain. Hal ini terapi wicara dan berbahasa akan sangat menolong.

\section{Terapi Okupasi}

Semua anak autistik mempunyai keterlambatan dalam perkembangan motorik halus. Gerak-geriknya kaku dan kasar, mereka kesulitan untuk memegang pensil dengan cara yang benar, kesulitan untuk memegang sendok dan menyuap makanan ke mulutnya dan lain sebagainya. Dalam hal ini terapi okupasi sangat penting untuk melatih mempergunakan otot-otot halusnya dengan benar.

\section{Terapi Interaksi Sosial}

Kekurangan yang paling mendasar bagi individu autisme adalah dalam bidang komunikasi dan interaksi. Banyak anak-anak ini membutuhkan pertolongan dalam keterampilan berkomunikasi dua arah, membuat teman dan main bersama di tempat bermain. Seorang terapis sosial membantu dengan memberikan fasilitas pada mereka untuk bergaul dengan teman-teman sebaya dan mengajari bagaimana caranya.

\section{Terapi Sensori Interaksi}

Terapi untuk melatih anak autis mengenai bagaimana ia mengatur informasi yang diperoleh dari lingkungan sekitar atau terapis, sehingga informasi tersebut dapat digunakan atau dilaksanakan sesuai dengan apa yang diperintahkan dan situasi yang ada.

\section{Terapi Makan (Motorik Mulut)}

Terapi makan ini berfungsi untuk menjaga pola makan dan untuk melatih anak agar bisa mengunyah. Hal ini juga bermanfaat agar nanti tidak sulit dalam melakukan melakukan terapi bicara. Anak autis atau hiperaktif rentan dengan penyakit untuk itu perlu menerapkan apa saja makanan yang harus dimakan dan apa saja yang harus diberikan kepada anak, karena apabila tidak sesuai dengan apa yang diperintahkan anak akan eror. Karena itu hal ini selalu ditekankan kepada orang tua apa saja yang tidak boleh dimakan dan diminum oleh anak. 


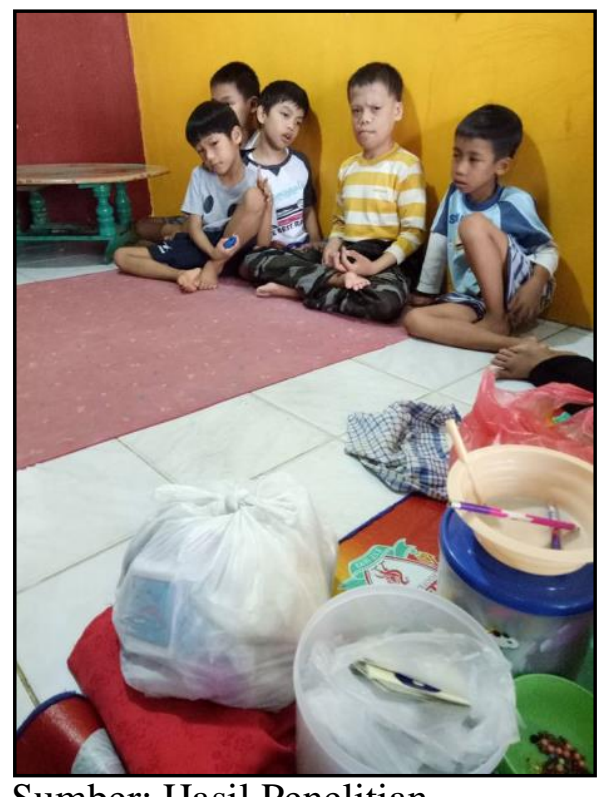

Sumber: Hasil Penelitian

Gambar 2. Terapi Makan Dalam Pendekatan Konvensional

Anak autis dan hiperaktif memiliki daya tubuh yang sangat lemah, karena itu makanan yang diberikan pada anak-anak tersebut harus seimbang. Tidak boleh memakan makan yang hanya memiliki vitamin A saja, tapi harus diimbangi dengan makanan yang memiliki vitamin lainnya. Kerjasama dengan dokter adalah yang penting agar memperkecil terjadinya gizi tidak seimbang. Memberikan obat-obatan yang sesuai dengan kebutuhan tubuh anak, biasanya kalau anak autis sakit atau demam diberikan obat khusus yang dosisnya rendah.

Cara untuk melatih anak dalam berkontak mata dengan kita, anak harus berhadapan dengan kita lalu dipanggil namanya. Kalau dia melihat kita walaupun cuma setengah detik lalu diberi reward seperti pintar lalu tepuk tangan, tapi kalau anak di panggil satu kali tidak melihat ulangi lagi terus sampai tiga kali kalau sudah sampai tiga kali anak tidak ada respon nanti ibu pendamping yang akan membantu melihatkan dengan kata "lihat ibu". Berhadapan dengan anak apabila anak dipanggil ada respon kasih reward dan cara untuk memanggil anak autis dengan memberikan penekanan suara ketika memanggil anak tersebut kita memanggilnya harus tegas.

Teknik lain untuk melatih kontak mata seperti memasukkan bola ke keranjang atau dengan menggunakan lampu ketika membaca. Kegiatan terapi di tempat ini sering dipublikasi melalui Facebook agar orang tua dari anak anak autis bisa melihat apa saja kegiatan yang dilakukan anak dan apa saja terapi yang digunakan agar orang tua bisa juga menerapkan trapi tersebut kepada anaknya pas di rumah.

\section{Simpulan}

Dalam terapi zikir seorang terapis menitikberatkan faktor rohani sehingga si anak disehatkan secara batin. Dengan terapi solat, zikir dan membaca Alquran yang dilakukan oleh terapis kepada anak agar mampu menjalankan rutinitas dan membuat mereka kembali kepada kenormalan. Terapi menggunakan pendekatan konvensional 
menitikberatkan kesehatan secara fisik. Untuk membuat klien yang memiliki gangguan autis dapat kembali normal digunakan terapi makan. Setelah terapi ini diterapkan dengan baik, maka anak akan dengan mudah diterapi wicara dan terapi lainnya. Awal kesembuhan klien adalah ketika klien mampu menjaga semua yang menjadi pemicu keautisan sehingga meminimalisir terjadinya eror, jika tidak ada eror anak autis akan mampu melakukan semua jenis terapi yang diberikan kepada mereka.

\section{Referensi}

Agustina, F. K. (2017). Keikutsertaan Care Giver Dalam Menerapkan Terapi ABA (Applied Behaviour Analysis) Pada Anak Autis Dipusat Terapi LPSDM Graha Jiwa Indonesia Kabupaten Pringsewu. Stikes Aisyah Pringeswu Lampung Program Studi Keperawatan.

Astuti, A., Suryono, S., Widyawati, M. N., Suwondo, A., \& Mardiyono, M. (2017). Effect Of Audio Therapy Using Al-Qur'an Murrotal On Behavior Development In Children With Autism. Belitung Nursing Journal, 3(5), 470-477.

Desiningrum, D. R. (2017). Psikologi Anak Berkebutuhan Khusus. Psikosain.

Hadi, M., \& Zubaidah, Z. (2015). Pemanfaatan Konseling Neuro Linguistic Programming Dalam Mengatasi Kesulitan Belajar Siswa Sekolah Dasar. Jurnal Dakwah Risalah, 26(4), 174-182. https://doi.org/10.24014/jdr.v26i4.1275

Hapsari, D. (2016). Pengaruh Terapi Murottal Surat Al-Mulk Terhadap Kemampuan Interaksi Sosial Pada Anak Autis Di Slb N 01 Bantul Yogyakarta.

Hasnita, E., \& Hidayati, T. R. (2017). Terapi Okupasi Perkembangan Motorik Halus Anak Autisme. Jurnal Ipteks Terapan, 9(1).

Ifdil, I., Zola, N., Putri, Y. E., Zatrahadi, M. F., Darmawati, D., \& Ardi, Z. (2019). Thanatophobia and its Treatment Using Neurolinguistic Programming. Addictive Disorders and Their Treatment. https://doi.org/10.1097/ADT.0000000000000186

Klin, A., Jones, W., Schultz, R., Volkmar, F., \& Cohen, D. (2002). Defining and Quantifying The Social Phenotype in Autism. American Journal of Psychiatry, 159(6), 895-908.

Kusumastuti, F. (2018). Tindakan Komunikatif Orang Tua Dalam Penanganan Anak Penyandang Autism (Studi fenomenologi pada Ibu-Ibu anggota Parent Support Group di Malang Raya). University Of Muhammadiyah Malang.

Mangunsong. (2009). Psikologi dan Pendidikan Anak berkebutuhan Khusus (1st ed.). Jakarta: LPSP3 UI.

Nurhidayati, Z. (2015). Pengaruh Pola Konsumsi Makanan Bebas Gluten Bebas Kasein dengan Gangguan Perilaku pada Anak Autistik. Jurnal Majority, 4(7), 121-128.

Purwanto, M. N. (1998). Ilmu Pendidikan Teoritis dan Praktis. Bandung: Remaja Rosdakarya.

Rifai, M. (2016). Peranan Orangtua Sebagai Wali, Pembimbing, Dan Pendidik Pada Perkembangan Anak Dalam Perspektif Pendidikan Agama Islam. Premiere Educandum: Jurnal Pendidikan Dasar Dan Pembelajaran, 1(01).

Risdayati, R., \& Merianto, R. W. (2016). Peran Orang Tua dalam Menangani Anak Autis (Studi Kasus 4 Keluarga Anak Autis di Kota Pekanbaru). Jurnal Online Mahasiswa Fakultas Ilmu Sosial Dan Ilmu Politik Universitas Riau, 3(1).

Sari, M., \& Yudhatama, Y. (2017). Pola Asuh Orang Tua terhadap Kejadian ECC (Early Childhood Caries) pada Anak Usia 3-5 Di Kelurahan Purwosari Kota 
Terapi Penyembuhan Autis Melalui Pendekatan.....

Surakarta. URECOL, 303-310.

Wikipedia. (n.d.). Autisme.

Wirapati, D. (2018). Sistem Pakar Diagnosa Jenis Autis Pada Anak Menggunakan Metode Naive Bayes Classifier. Universitas Mercu Buana Yogyakarta.

Yayasan Penyelenggara Penterjemah atau Penafsir Al-Qur'an, (terj) Lajnah Pentashih Mushaf Al-Qur'an Departemen Agama Republik Indonesia. (2004). Al-Qur'an dan Terjemahnya; Al-Jumanatul Ali (Seuntai Mutiara Yang Maha Luhur). Bandung: JART.

Yunus, A. (2016). Perancangan Aplikasi Pembelajaran Menggambar Bangun Datar Untuk Anak Autis Berbasis Android. Universitas Widyatama. 